\title{
FOXP3 expression of micrometastasis-positive sentinel nodes in breast cancer patients
}

\author{
KAZUO MATSUURA ${ }^{1,3}$, YOSHIYUKI YAMAGUCHI ${ }^{1}$, AKIHIKO OSAKI $^{1,3}$, MASAHIRO OHARA $^{1}$, \\ RIKI OKITA $^{1}$, AKIKO EMI $^{1}$, SHIGERU MURAKAMI ${ }^{1}$ and KOJI ARIHIRO ${ }^{2}$ \\ Departments of ${ }^{1}$ Surgical Oncology, Research Institute for Radiation Biology and Medicine, and \\ ${ }^{2}$ Anatomical Pathology, Hiroshima University, Hiroshima, Japan
}

Received June 18, 2009; Accepted July 23, 2009

DOI: $10.3892 /$ or_00000553

\begin{abstract}
A number of methods have been established for identifying sentinel nodes (SNs). In the present study, we attempted to clarify the immunological status of SNs with or without micrometastasis in breast cancer patients. SNs were identified by the dye- and $\gamma$ probe-guided method. Total RNA was extracted from the SNs, and the expression of T-BET, GATA-3, and FOXP3 were evaluated using quantitative realtime reverse transcriptase-polymerase chain reaction (RTPCR). Micrometastasis was identified as microscopically negative but positive by RT-PCR specific for mammaglobin. Of 88 patients, $17(19.3 \%)$ showed positive metastasis in SNs (pN1, 14; pN2, 3). Of the 71 metastasis-negative SNs, 11 showed positive bands on RT-PCR specific for mammaglobin $[\mathrm{pNO}(\mathrm{mol}+)]$. There was no significant correlation among clinicopathological features with or without micrometastasis. Immunological parameters were compared among the $60 \mathrm{pN} 0,11 \mathrm{pNO}(\mathrm{mol}+)$, and $17 \mathrm{pN1}-2$. Although $T$-BET expression was higher in $\mathrm{pN} 0(\mathrm{~mol}+)$ than $\mathrm{pN} 0, F O X P 3$ expression was also higher in $\mathrm{pNO}(\mathrm{mol}+)$ than $\mathrm{pN} 0$. In $\mathrm{pN} 1-2$, $T$-BET expression decreased compared with $\mathrm{pN} 0(\mathrm{~mol}+)$, but FOXP3 expression did not. On the other hand, GATA-3 expression inversely increased in $\mathrm{pN} 1-2$ compared with pNO(mol+). In patients with breast cancer, micrometastasis can stimulate Th1 response in SNs. However, the Treg cell response is also induced at the micrometastasis level and persists during the progression of metastasis in SNs. Then, the shift in the Th1/Th2 balance may preferentially lean toward Th2 responses in pN1-2 SNs and suppress antitumor immune responses. Micrometastasis $[\mathrm{pNO}(\mathrm{mol}+)]$ is a status immunologically distinguishable from $\mathrm{pN} 0$ and $\mathrm{pN} 1-2$.
\end{abstract}

Correspondence to: Dr Kazuo Matsuura, ${ }^{3}$ Present address: Department of Breast Oncology, Saitama Medical University International Medical Center, 1397-1 Yamane, Hidaka-shi, Saitama 350-1298, Japan

E-mail:m79kazuo@saitama-med.ac.jp

Key words: breast cancer, sentinel nodes, micrometastasis, FOXP3, T-BET, GATA-3

\section{Introduction}

Draining lymph nodes that are targeted to be reached first by tumor cell metastasis have been identified as the sentinel nodes (SNs) (1). The SN concept is one of the most highlighted issues in recent surgical oncology, and staging merits and individualized surgical management have been proposed for melanoma $(2)$ breast cancer $(3,4)$ and upper gastrointestinal (GI) cancer (5) based on the SN concept. This has become possible due to the establishment of a methodology for detecting SNs $(2,4,5)$. However, few reports to date have clarified the immunological status of SNs and non-SNs in cancer patients $(6,7)$.

Mature dendritic cells (DCs) contribute significantly to antigen presentation, which results in the emergence of antigen-specific immune responses, including T-helper type 1 (Th1) responses, which is desirable for antimetastatic responses (8). Th1 cells are identified by $T-B E T$, a novel member of the T-box family of transcription factors, which was originally cloned both by virtue of its ability to bind to the Th1-specific interleukin (IL)-2 promoter, and by its expression in Th1 but not Th2 cells (9). On the other hand, Th2 responses, which represent IL-4 or IL-10 production (10) are identified by GATA-3, a member of the GATA family of zinc finger proteins which is a Th2-specific transcription factor (11).

In the immune regulation between $\mathrm{Th} 1$ and $\mathrm{Th} 2$ responses, regulatory $\mathrm{T}$ (Treg) cell responses, which are identified by $\mathrm{CD} 4{ }^{+} \mathrm{CD} 25^{+}$cells and $F O X P 3$ expression, 12 have been recognized as serving in anti-Th1, anti-defense responses $(10,13)$ and may have a deleterious effect in suppressing antitumor immune responses (14). Our previous study (15) showed that, when comparing among metastasis-negative breast cancer patients, populations of HLA-DR, CD80, CD86 and CD40 as assessed by flow cytometric analysis (FCM) and the expression of CD83 and IFN- $\gamma$ determined by quantitative real-time reverse transcriptase-polymerase chain reaction (RT-PCR) were depressed in SNs more than in non-SNs. When comparing microscopically metastasis-negative with positive SNs, the expression of CD83, IL-12p40 and IFN- $\gamma$ as determined by quantitative real-time RT-PCR increased more in metastasis-positive than in -negative SNs. These results clearly indicate that the immunological status of SNs, including DC maturation and Th1 responses, is depressed in SNs before 
metastasis, but is up-regulated after metastasis occurs. However, we did not clarify the immunological status of micrometastasis-positive SNs.

In the present study, we addressed the immunological status of SNs, especially those with micrometastasis, based on Th1, Th2 cell responses and on Treg cell responses, and examined their clinicopathological significance in breast cancer patients.

\section{Materials and methods}

Patients. Our subjects were adult female patients with primary breast cancer who underwent SN biopsy as part of their surgical treatment at Hiroshima University Hospital between 2001 and 2005. Each of the patients had clinically NO lymph node metastasis. The study was approved by the institutional review board of Hiroshima University Hospital, and written informed consent was obtained from all enrolled patients.

Detection of SNs. Detection of SNs was performed using two independent methods: the dye- and $\gamma$ probe-guided method. In brief, $1 \mathrm{ml}$ of ${ }^{99 \mathrm{~m}} \mathrm{Tc}$-phytate $(0.5 \mathrm{mCi}$ total $)$ was injected intradermally at the site of the breast tumor 1 day before surgery. Indigo carmine dye $(3 \mathrm{ml})$ was injected intra- and subcutaneously at the areola of the nipple under general anesthesia immediately before starting the operation. During surgery, the radiation levels of each node were assessed using a navigational global positioning system (Tyco Electronics Japan). Lymph nodes displaying radioactivity in excess of 10 cps were considered SNs. SNs were also detected as blue nodes; non-blue-dying lymph nodes demonstrating an uptake of less than $10 \mathrm{cps}$ in the same surgical fields were regarded as non-SNs. We identified a total of 88 SNs.

Detection of metastasis. Each SN was immediately cut into two pieces, one of which was subjected to histological analysis, while the other half was frozen for mRNA analysis. To detect micrometastases, mammaglobin expression, which is the most informative marker for lymph node metastasis of breast cancer (16) was analyzed by quantitative real-time RT-PCR.

Tumors studied. The histological type of each tumor was evaluated based on a representative hematoxylin-eosin (HE) specimen of the tumor and a nuclear grade was assigned according to the standard scoring system (17-19).

Immunohistochemistry. Three sections $4 \mu \mathrm{m}$ in thickness were serially cut from formalin-fixed, paraffin-embedded tissues and mounted on precoated slides. Evaluation of the status of estrogen receptor (ER) and progesterone receptor $(\mathrm{PgR})$ was performed in the standard manner by immunohistochemistry (IHC) using a Ventana HX system BenchMark (Ventana Medical Systems, Tucson, AZ, USA). Anti-ER mouse monoclonal antibody (mAb), 6F11 (Ventana) and anti-PgR mAb, 16 (Ventana) were used. All procedures were performed automatically by the BenchMark. IHC findings of ER and PgR were evaluated using Allred score, whose cut-off value has been clinically validated in several studies (20-24). To evaluate Her2 protein, a Herceptest was performed on each tumor (Dako, Glostrup, Denmark) and scored according to Herceptest criteria.

Quantitative RT-PCR. Stored SN tissues were subjected to total RNA extraction using an RNeasy Mini Kit (Qiagen, Hilden, Germany). DNase I treatment was performed during the protocol to avoid amplification of pseudogene sequences from contaminating genomic DNA. The quality and quantity of the obtained total RNA preparation were determined by absorbance at 260 and $280 \mathrm{~nm}$, and adjusted at a concentration of $0.10 \mu \mathrm{g} / \mu \mathrm{l}$. The prepared total RNA served as the template for the first-strand cDNA synthesis using Ready-To-Go ${ }^{\text {TM }}$ You-Prime-First-Strand Beads (Amersham Pharmacia Biotech Inc., Piscataway, NJ, USA) with $0.5 \mu \mathrm{g}$ of Oligo(dT)15 primer (Novagen, Darmstadt, Germany) following the manufacturer's instructions. Each cDNA product was diluted 10-fold with RNase-free water, and PCR was carried out using a LightCycler with software version 3.5 (Roche Diagnostics, Mannheim, Germany) using a FastStart DNA Master SYBR-Green I Kit (Roche Diagnostics). For each primer pair, the amplification conditions and calibration curves were the same as those described previously in our own study (15) and in that of Ueno et al (25). The primers for FOXP3, T-BET, GATA-3 and glyceraldehyde-3phosphate dehydrogenase (GAPDH) were obtained from Search-LC GmbH (Heidelberg, Germany). The sequences of the mammaglobin primer pairs used were 5'-cggatgaaactctg agcaatgt-3' and 5'-ctgcagttctgtgagccaaag-3' (26). All clinical samples from patients with breast cancer were analyzed in parallel with standard samples from Search-LC, calculating the copy numbers on LightCycler software version $3.5(15,25)$.

Statistical analysis. Clinicopathological features associated with SNs were evaluated by the $\chi^{2}$ test and the MannWhitney U-test. Because of the skewed nature of some of the RT-PCR data, differences between unpaired groups were evaluated by the Mann-Whitney's U-test, and differences among multi-groups were evaluated by the Kruskal-Wallis test using StatView software (Version 5; SAS Institute Inc., Cary, NC, USA) on a Windows computer. P-values of $<0.05$ were considered significant.

\section{Results}

Patient characteristics and SN status. The characteristics of the 88 patients enrolled are shown in Table I. The enrolled patients were $55.1 \pm 11.7$ years old (mean \pm standard deviation) in age, ranging from 33 to 79 . Breast-conserving surgery and mastectomy were performed for $63(72 \%)$ and $25(28 \%)$ of patients, respectively. Pathological tumor size ranged from 0 to $4.6 \mathrm{~cm}$ in diameter, including non-invasive carcinoma. Approximately two-thirds of the tumors expressed estrogen and progesterone receptors $(60 \%)$. One fifth of the tumors were HER 2 positive. More than half of the patients were assigned nuclear grade 2-3 (56\%). Forty-three percent of the patients exhibited no trend of invasion into lymphatics (ly0), and $86 \%$ no trend of venous invasion (v0).

Of the 88 SNs studied, 17 were histologically diagnosed as metastasis-positive (pN1-2), and 71 were defined as metastasis-negative (n0); n0 tumors were further analyzed by RT- 
Table I. Clinicopathological features of the examined SNs.

\begin{tabular}{|c|c|c|c|c|c|}
\hline \multirow[b]{2}{*}{ Features } & \multirow[b]{2}{*}{$\begin{array}{c}\text { Total } \\
(\mathrm{n}=88)(\%)\end{array}$} & \multicolumn{3}{|c|}{ SN metastasis status: no. of patients (\%) } & \multirow[b]{2}{*}{ p-value } \\
\hline & & $\begin{array}{l}\text { pN0 SNs } \\
(\mathrm{n}=60)(\%)\end{array}$ & $\begin{array}{l}\mathrm{pNO}(\mathrm{mol}+) \mathrm{SNs} \\
(\mathrm{n}=11)(\%)\end{array}$ & $\begin{array}{c}\mathrm{pN} 1-2 \\
(\mathrm{n}=17)(\%)\end{array}$ & \\
\hline \multicolumn{6}{|l|}{ Age (years) } \\
\hline Mean \pm SD & $55.1 \pm 11.7$ & $54.6 \pm 12.5$ & $56.0 \pm 10.6$ & $56.5 \pm 9.6$ & 0.7793 \\
\hline Range & 33-79 & 33-79 & 40-75 & 41-74 & \\
\hline \multicolumn{6}{|l|}{ Type of surgery } \\
\hline Breast-conserving & $63(72)$ & $49(82)$ & $6(55)$ & $8(47)$ & 0.0082 \\
\hline Mastectomy & $25(28)$ & $11(17)$ & $5(45)$ & $9(53)$ & \\
\hline \multicolumn{6}{|l|}{ Tumor size $(\mathrm{cm})$} \\
\hline Mean \pm SD & $2.2 \pm 1.1$ & $2.2 \pm 1.4$ & $2.7 \pm 1.4$ & $2.3 \pm 1.1$ & 0.3758 \\
\hline Range & $0.0-4.6$ & $0.0-4.4$ & $1.0-4.4$ & $0.8-4.6$ & \\
\hline \multicolumn{6}{|l|}{ Hormone receptor status } \\
\hline ER+ and $\mathrm{PgR}+$ & $53(60)$ & $38(63)$ & $6(55)$ & $9(53)$ & 0.1693 \\
\hline $\mathrm{ER}+$ or $\mathrm{PgR}+$ & $12(14)$ & 7 (12) & $3(27)$ & $2(12)$ & \\
\hline ER- and PgR- & $14(16)$ & $6(10)$ & $2(18)$ & $6(35)$ & \\
\hline Unknown & $9(10)$ & $9(15)$ & $0(0)$ & $0(0)$ & \\
\hline \multicolumn{6}{|l|}{ HER2 status } \\
\hline Negative & $57(65)$ & $36(60)$ & $7(64)$ & $14(82)$ & 0.6772 \\
\hline Positive & $14(16)$ & $8(13)$ & $3(27)$ & $3(18)$ & \\
\hline Unknown & 17 (19) & $16(27)$ & $1(9)$ & $0(0)$ & \\
\hline \multicolumn{6}{|l|}{ Nuclear grade } \\
\hline I & $28(32)$ & $20(33)$ & $5(45)$ & $3(18)$ & 0.463 \\
\hline II & $30(34)$ & $17(28)$ & $4(36)$ & $9(53)$ & \\
\hline III & $19(22)$ & $12(20)$ & $2(18)$ & $5(29)$ & \\
\hline Unknown & $11(13)$ & $11(18)$ & $0(0)$ & $0(0)$ & \\
\hline \multicolumn{6}{|l|}{ Lymphatic invasion score } \\
\hline 0 & $38(43)$ & $32(53)$ & $6(55)$ & $0(0)$ & $<0.0001$ \\
\hline 1 & $29(33)$ & $17(28)$ & $3(27)$ & $9(53)$ & \\
\hline 2 & $9(10)$ & $0(3)$ & $2(18)$ & $7(41)$ & \\
\hline 3 & $1(1)$ & $0(0)$ & $0(0)$ & $1(6)$ & \\
\hline Unknown & $11(13)$ & $11(18)$ & $0(0)$ & $0(0)$ & \\
\hline \multicolumn{6}{|l|}{ Vascular invasion score } \\
\hline 0 & $76(86)$ & $49(82)$ & $11(100)$ & $16(94)$ & 0.1673 \\
\hline 1 & $1(1)$ & $0(0)$ & $0(0)$ & $1(6)$ & \\
\hline Unknown & $11(13)$ & $11(18)$ & $0(0)$ & $0(0)$ & \\
\hline \multicolumn{6}{|l|}{ Histological classification } \\
\hline DCIS & $8(9)$ & $8(13)$ & $0(0)$ & $0(0)$ & 0.1595 \\
\hline Papillotubular carcinoma & $22(25)$ & $17(28)$ & $2(18)$ & $3(18)$ & \\
\hline Solid tubular carcinoma & $25(28)$ & $15(25)$ & $3(27)$ & $7(41)$ & \\
\hline Scirrous carcinoma & $24(27)$ & $12(20)$ & $5(45)$ & $7(41)$ & \\
\hline Others & $9(10)$ & $8(13)$ & $1(9)$ & $0(0)$ & \\
\hline
\end{tabular}

SN, sentinel lymph node; Mean \pm SD, mean \pm standard deviation; ER, estrogen receptor; PgR, progesterone receptor; DCIS, ductal carcinoma in situ. An immunohistochemical (IHC) study of Her-2/neu was conducted, followed by fluorescent in situ hybridization (FISH) validation for Her-2/neu gene amplification in cases initially scored as positive $2+$ by IHC.

PCR specific for mammaglobin to examine the possibility of microscopically negative but RT-PCR-positive micro- metastasis. Among the $71 \mathrm{n} 0 \mathrm{SNs}, 11$ showed positive bands on the RT-PCR [pNO(mol+)]. When the $60 \mathrm{pN} 0,11$ 
Table II. Comparison of immunological parameters analyzed using RT-PCR in non-invasive carcinoma and invasive carcinoma in 60 cases of pNO SNs.

\begin{tabular}{lccr}
\hline & \multicolumn{2}{c}{ Copy number } & \\
\cline { 2 - 3 } Expression & $\begin{array}{c}\text { Non-invasive } \\
\text { carcinoma }(\mathrm{n}=9)\end{array}$ & $\begin{array}{c}\mathrm{pN} 0 \text {-invasive } \\
\text { carcinoma }(\mathrm{n}=51)\end{array}$ & P-value \\
\hline T-BET & $101.3 \pm 71.3$ & $258.2 \pm 315.4$ & 0.3305 \\
GATA-3 & $2045.8 \pm 1691.4$ & $2066.6 \pm 1594.9$ & 0.9587 \\
Th2/Th1 & $23.2 \pm 27.6$ & $51.7 \pm 100.0$ & 0.6864 \\
FOXP3 & $454.0 \pm 414.8$ & $412.5 \pm 401.7$ & 0.7249 \\
\hline
\end{tabular}

Copy numbers (mean \pm standard deviation) were compared in 60 cases of pNO SNs between non-invasive carcinoma and invasive carcinoma SNs and are shown as p-values. Definition of Th1/Th2 ratio is the calculation of $T-B E T / G A T A-3$ ratio.

pN0(mol+) and $17 \mathrm{pN1}$-2 tumors in breast cancer patients were compared, no significant differences were found in mean age, tumor size, steroid receptor status, HER2 expression, nuclear grade or venous invasion levels (Table I). Patients with pNO SNs underwent breast-conserving surgery significantly more often than those with pNO(mol+) SNs or pN1-2 SNs (pN0, 82\% vs. pNO(mol+), 55\% vs. pN1-2 47\%; $\mathrm{p}=0.0082$ ). The potential for lymphatic invasion (ly) was significantly higher in the tumors from patients with $\mathrm{pNO}(\mathrm{mol}+)$ and $\mathrm{pN} 1-2$ SNs than in those from patients with pNO SNs (ly0 $53 \%$ vs. $55 \%$ vs. $0 \%$; 1 y $1,28 \%$ vs. $27 \%$ vs. $53 \%$; ly $2,0 \%$ vs. $18 \%$ vs. $41 \%$; $1 \mathrm{y} 3,0 \%$ vs. $0 \%$ vs. $6 \%$; p<0.0001) (Table I).

Comparison of immunological parameters of $p N O$, $p N O(m o l+)$ and pN1-2. Immunological status including Th1, Th2 and Treg responses was analyzed in 60 cases of pN0, 11 of $\mathrm{pNO}(\mathrm{mol}+)$, and 17 of pN1-2 SNs (Table III). There is no significant difference of the copy number of T-BET, GATA-3, and FOXP3 in 60 cases of pNO SNs between non-invasive carcinoma and invasive carcinoma (Table II). The copy number of $T$-BET showed a significant difference among the three groups (pN0 SNs, 234.7 \pm 296.9 vs. pNO(mol+) SNs, $425.4 \pm 540.1$ vs. pN1-2 SNs, 319.5 \pm 337.3 ; $\mathrm{p}=0.0421$ ). Although there was no significant difference in the expression of GATA-3 between pNO $(2063.5 \pm 1594.9)$ and $\mathrm{pNO}(\mathrm{mol}+)$ SNs (2747.8 \pm 2649.3$),$ GATA-3 expression was significantly higher in $\mathrm{pN} 1-2$ SNs $(21908.5 \pm 34882.9)$ than in $\mathrm{pN} 0$ or pN0(mol+) SNs $(\mathrm{p}<0.0001)$. The Th2/Th1 ratio was also significantly higher in pN1-2 SNs $(160.6 \pm 292.7)$ than in $\mathrm{pN} 0$ SNs (47.5 \pm 93.2$)$ or $\mathrm{pNO}(\mathrm{mol}+)$ SNs $(13.9 \pm 19.4)(\mathrm{p}=0.0114)$. The copy number of FOXP3 was significantly higher in pN0(mol+) SNs $(914.8 \pm 816.1)$ and pN1-2 SNs (959.0 \pm 686.8$)$ than in pN0 SNs $(418.7 \pm 400.4)(\mathrm{p}=0.0017)$ (Table III).

Comparison of immunological parameters in metastasisnegative and-positive patients with respect to clinicopathological features. We compared immunological parameters between metastasis-negative (pN0) and -positive [pNO(mol+) and $\mathrm{pN} 1-2]$ patients with respect to clinicopathological features. Although no significant differences were found in Her2 expression, tumor grade or venous invasion levels (data not shown), the status of steroid hormone receptors appeared to influence immunological status. The malignant potential of certain hormonal status groups (ER and PgR-) was higher, and more Treg cells were induced in metastasis-positive SNs than in metastasis-negative SNs in the present study (data not shown).

\section{Discussion}

In the present study, we questioned whether or not the immunological status of SNs, including the response and

Table III. Comparison of immunological parameters analyzed using RT-PCR in pN0, pN0(mol+) and pN1-2 SNs.

\begin{tabular}{|c|c|c|c|c|c|}
\hline \multirow[b]{2}{*}{ Expression } & \multicolumn{4}{|c|}{ Copy number } & \multirow[b]{2}{*}{$\mathrm{P}$-value } \\
\hline & $\begin{array}{c}\mathrm{pN} 0 \\
(\mathrm{n}=60)\end{array}$ & & $\begin{array}{c}\mathrm{pN} 0(\mathrm{~mol}+) \\
(\mathrm{n}=11)\end{array}$ & $\begin{array}{l}\mathrm{pN} 1-2 \\
(\mathrm{n}=17)\end{array}$ & \\
\hline \multirow[t]{2}{*}{$T-B E T$} & $234.7 \pm 296.9$ & & $425.4 \pm 540.1$ & $319.5 \pm 337.3$ & 0.0421 \\
\hline & & $\mathrm{b}$ & & $\mathrm{b}$ & \\
\hline \multirow[t]{2}{*}{ GATA-3 } & $2063.5 \pm 1594.9$ & & $2747.8 \pm 2649.3$ & $21908.5 \pm 34882.9$ & $<0.0001$ \\
\hline & & a & 1 & a & \\
\hline \multirow[t]{2}{*}{ Th2/Th1 } & $47.5 \pm 93.2$ & & $13.9 \pm 19.4$ & $160.6 \pm 292.7$ & 0.0114 \\
\hline & & a & & $\mathrm{b}$ & \\
\hline FOXP3 & $418.7 \pm 400.4$ & & $914.8 \pm 816.1$ & $959.0 \pm 686.8$ & 0.0017 \\
\hline
\end{tabular}

SNs were obtained by SN biopsy from patients with breast cancer. RNA was extracted and subjected to quantitative RT-PCR analysis specific for the immunological parameters indicated. Copy numbers (mean \pm standard deviation) were compared among $\mathrm{pN} 0, \mathrm{pNO}(\mathrm{mol}+)$ and pN1-2 SNs and are shown as p-values. Differences were compared among the three SN groups $\left({ }^{\mathrm{a}} \mathrm{p}<0.05 ;{ }^{b} \mathrm{p}<0.01\right)$. Definition of Th1/Th2 ratio is the calculation of $T-B E T / G A T A-3$ ratio. 


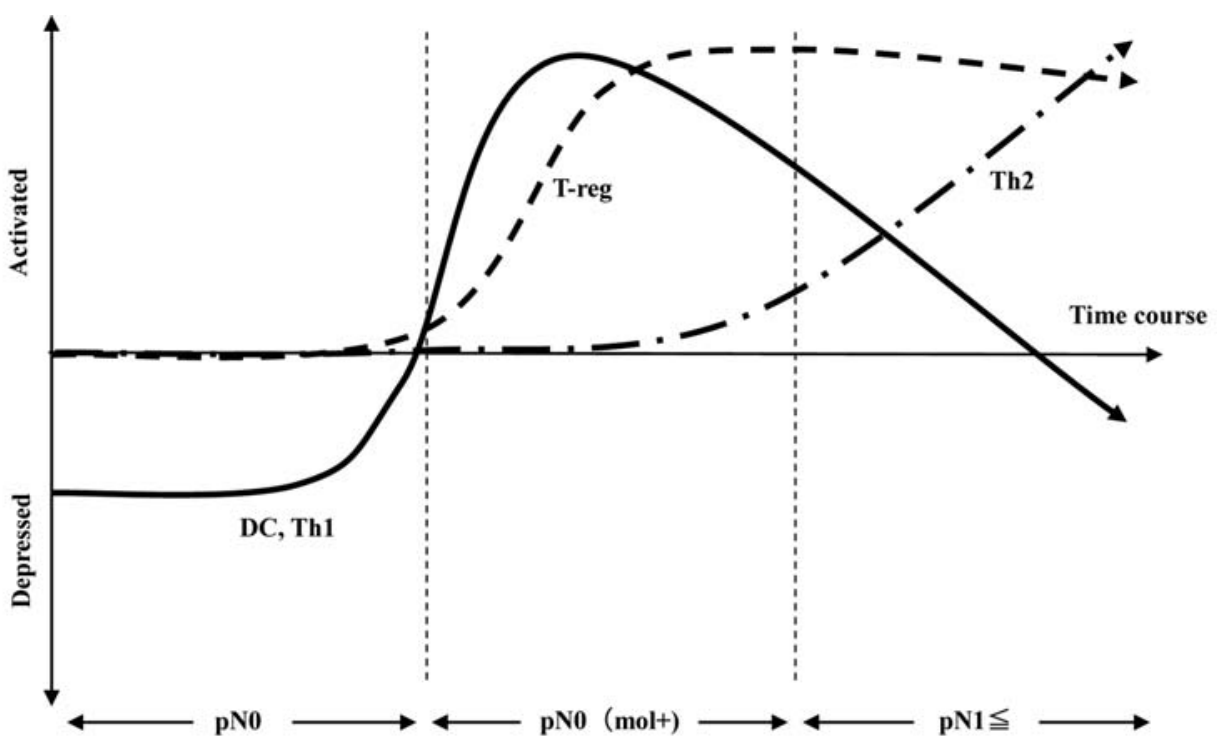

The immunological status of SNs.

Figure 1. Proposal of the immunological dynamics of SN immunity with or without metastasis. The immunological status of SNs, including DC maturation and Th1 responses, was depressed in SNs before metastasis. The up-regulation of Th1 and Treg responses was induced at the micrometastasis level, followed by the down-modulation of Th1 responses and the up-regulation of Th2 responses along with enlargement of metastasis in SNs. Micrometastasis [pNO(mol+)] is a status immunologically distinguishable from pN0 and pN1-2. DC, dendritic cell; Treg, regulatory T cell; Th1, 2, T-helper type-1, 2.

balance of Th1/Th2 cells and Treg cells, is activated. Our previous results (15) clearly indicate that the immunological status of SNs, including DC maturation and Th1 responses, is depressed in SNs before metastasis, but is up-regulated after metastasis occurs. In the present study, it was found that Th1 responses were up-regulated even in SNs with micrometastasis [pNO(mol+)]. These responses are not influenced by primary tumor but by micrometastasis [pNO(mol+)] because there is no significant difference of immunological parameters of $\mathrm{pNO}$ SNs between non-invasive carcinoma and invasive carcinoma. Importantly, up-regulation of Treg cells was also found to occur without up-regulation of Th2 in the micrometastasis-positive $\mathrm{SNs}[\mathrm{pNO}(\mathrm{mol}+)]$ in the present study, indicating that $\mathrm{pNO}(\mathrm{mol}+) \mathrm{SNs}$ are immunologically distinguishable from $\mathrm{pNO}$ and $\mathrm{pN} 1-2$ SNs. In addition, the present study indicated that the shift of the Th1/Th2 balance might preferentially lean toward Th2 and suppress antitumor immune responses as the metastasis grew larger. Taken together, it appears that immunological changes occur in SNs along with the development of metastasis, as shown in Fig. 1. These findings dramatically alter our understanding of depressed cellular immune function in patients with breast cancer and advance the role of Treg cells in facilitating tumor immune evasion in SNs.

It is an interesting question whether Treg cells are involved in the development of the Th1/Th2 balance. Stassen et al (27) recently specified parameters governing the regulatory capacity of natural CD25+ Treg cells on the development, functional activation and proliferation of Th2 cells, and demonstrated that $\mathrm{CD} 25^{+}$Treg cells can suppress the differentiation of Th2 cells in a contact-dependent manner. Benghiat et al (28) have reported in a mouse model of acute allograft rejection that the depletion of Treg cells enhances both Th1 and Th2 cyto- kine production by $\mathrm{CD} 4^{+} \mathrm{T}$ cells and, reciprocally, that the addition of purified natural CD25+ Treg cells suppress both cytokines in a dose-dependent manner. These observations are in keeping with another report indicating that natural CD25+ Treg cells suppress Th1 and Th2 responses during experimental Leishmania major infection (29). On the other hand, Suto et al (30) have demonstrated that Treg cell depletion decreases the differentiation of antigen-induced Th2 cells with IL- 4 and IL-5 production, but increases Th1 differentiation in a mouse model of Th2-mediated allergic inflammation in the airways, indicating the possibility that CD ${ }^{+} \mathrm{CD} 25^{+}$Treg cells may modulate the Th1/Th2 balance toward Th2 cells and up-regulate Th2 cells. In the present study, it was observed that the expression of FOXP3 was up-regulated in pNO(mol+) SNs, which was followed by the up-regulation of Th2 expression in pN1-2 SNs, suggesting the involvement of Treg cells in the modulation of Th1 to Th2 responses in SNs. During the establishment of micrometastasis and its enlargement in SNs, Treg cells may be activated and, in turn, may up-regulate Th2 cells.

On the other hand, Zuo et al (31) demonstrated that FOXP3 is an X-linked breast cancer suppressor gene and an important regulator of the HER-2/ErbB2 oncogene. They showed low levels of FOXP3 mRNA, which expressed less than a half of HPRT mRNA and CK19 mRNA, in the mice breast tissues and human breast tumor cell lines which were especially ER-positive breast cancer and normal breast epithelium. We confirmed low levels of FOXP3 mRNA, which did not affect high level of FOXP3 produced by Treg cells in SNs, in the breast tumor cell line (data not shown). In addition, we demonstrated that the copy number of FOXP3 was the same level between in $\mathrm{pNO}(\mathrm{mol}+) \mathrm{SNs}$ and in $\mathrm{pN} 1-2$ $\mathrm{SNs}$ in spite of metastasis-size in SNs (Table III), and 
significantly higher in $\mathrm{pNO}(\mathrm{mol}+)$ and $\mathrm{pN} 1-2 \mathrm{SNs}$ than in pN0 SNs in the hormonal status of ER and PgR- (data not shown), suggesting that FOXP3 expression, we observed here, can be interpreted as Treg cell origin.

The correct identification of the immunological status of SNs is important in order to develop novel immunotherapies of SN activation. In a study of gastric cancer (32) the biological and clinical significance of isolated tumor cells and micrometastasis in the lymph nodes has been discussed using an animal model. It was found that natural killer (NK) cellmediated immunity plays an important role in the inhibition of lymph node metastasis, especially in the early stage of metastasis development, including isolated tumor cells, and that the factor most responsible for the regression of isolated tumor cells after primary tumor resection is the immunologic activity conferred by NK cells against metastatic tumor cells in the lymph nodes. Furthermore, it has been proposed that micrometastasis in the early stage may be a good therapeutic target to prevent recurrence in the form of lymph node metastasis by immunotherapy that potentiates NK cell activity, such as IL-2 or IL-12 $(33,34)$. In breast cancer research, Comes et al have indicated that immunotherapy for micrometastases using an IL-21-based cellular vaccine is strongly potentiated by Treg cell depletion, using a single dose of a depleting anti-CD25 mAb (35). The present results may support the potential benefit of Treg cell-attenuating immunotherapy, even in a micrometastasis stage.

In summary, we examined the immunological status of SNs based on Th1, Th2 and Treg cell responses by focusing on the micrometastasis of $\mathrm{SNs}$ in breast cancer patients. Micrometastasis [pNO(mol+)] is a status immunologically distinguishable from $\mathrm{pN} 0$ and $\mathrm{pN} 1-2$. The up-regulation of Th1 and Treg responses occurred at the micrometastasis level, followed by the down-modulation of Th1 and the up-regulation of Th2 responses together with enlargement of the metastasis in SNs. The clinical significance of micrometastasis in SNs may emphasize immunotherapy for SN activation in patients with breast cancer.

\section{References}

1. Gould EA, Winship T, Philbin PH and Kerr HH: Observation on a 'sentinel node' in cancer of the parotid. Cancer 13: 77-78, 1960.

2. Morton DL, Wen DR, Wong JH, Economou JS, Cagle LA, Storm FK, Foshag LJ and Cochran AJ: Technical details of intraoperative lymphatic mapping for early stage melanoma. Arch Surg 127: 392-399, 1992

3. Giuliano AE, Kirgan DM, Guenther JM and Morton DL: Lymphatic mapping and sentinel lymphadenectomy for breast cancer. Ann Surg 220: 391-401, 1994

4. Krag DN, Weaver DL, Alex JC and Fairbank JT: Surgical resection and radiolocalization of the sentinel lymph node in breast cancer using a gamma probe. Surg Oncol 2: 335-340, 1993.

5. Kitagawa Y, Fujii H, Mukai M, Kubota T, Ando N, Watanabe M, Ohgami M, Otani Y, Ozawa S, Hasegawa H, Furukawa T, Kumai K, Ikeda T, Nakahara T, Kubo A and Kitajima M: The role of the sentinel lymph node in gastrointestinal cancer. Surg Clin North Am 80: 1799-1809, 2000.

6. Leong SP, Peng M, Zhou YM, Vaquerano JE and Chang JW: Cytokine profiles of sentinel lymph nodes draining the primary melanoma. Ann Surg Oncol 9: 82-87, 2002.

7. Ishigami S, Natsugoe S, Uenosono $Y$, Hata $Y$, Nakajo A, Miyazono F, Matsumoto M, Hokita S and Aikou T: Infiltration of antitumor immunocyes into the sentinel node in gastric cancer. J Gastroint Surg 7: 735-739, 2003.
8. Rieser C, Ramoner R, Holtl L, Rogatsch H, Papesh C, Stenzl A, Bartsch $\mathrm{G}$ and Thurnher M: Mature dendritic cells induce Thelper type-1-dominant immune responses in patients with metastatic renal cell carcinoma. Urol Int 63: 151-159, 1999.

9. Szabo SJ, Kim ST, Costa GL, Zhang X, Fathman CG and Glimcher LH: A novel transcription factor, T-bet, directs Th1 lineage commitment. Cell 100: 655-669, 2000.

10. Halak BK, Maguire HC and Lattime EC: Tumor-induced interleukin-10 inhibits type 1 immune responses directed at a tumor antigen as well as a non-tumor antigen present at the tumor site. Cancer Res 59: 911-917, 1999.

11. Zhang DH, Cohn L, Ray P, Bottomly K and Ray A: Transcription factor GATA-3 is differentially expressed in murine Th1 and Th2 cells and controls Th2-specific expression of the interleukin-5 gene. J Biol Chem 272: 597-603, 1997.

12. Hori S, Nomura T and Sakaguchi S: Control of regulatory T cell development by the transcription factor Foxp3. Science 299: 1057-1061, 2003.

13. Ichihara F, Kono K, Takahashi A, Kawaida H, Sugai $\mathrm{H}$ and Fujii $\mathrm{H}$ : Increased populations of regulatory $\mathrm{T}$ cells in peripheral blood and tumor-infiltrating lymphocytes in patients with gastric and esophageal cancers. Clin Cancer Res 9: 4404-4408, 2003.

14. Shimizu J, Yamazaki S and Sakaguchi S: Induction of tumor immunity by removing $\mathrm{CD} 25^{+} \mathrm{CD} 4^{+} \mathrm{T}$-cells: a common basis between tumor immunity and autoimmunity. J Immunol 163 : 5211-5218, 1999.

15. Matsuura K, Yamaguchi Y, Ueno H, Osaki A, Arihiro K and Toge T: Maturation of dendritic cells and T-cell responses in sentinel lymph nodes from patients with breast carcinoma. Cancer 106: 1227-1236, 2006.

16. Gillanders WE, Mikhitarian K, Hebert R, Mauldin PD, Palesch Y, Walters C, Urist MM, Mann GB, Doherty G, Herrmann VM, Hill AD, Eremin O, El-Sheemy M, Orr RK, Valle AA, Henderson MA, Dewitty RL, Sugg SL, Frykberg E, Yeh K, Bell RM, Metcalf JS, Elliott BM, Brothers T, Robison J, Mitas M and Cole DJ: Molecular detection of micrometastatic breast cancer in histopathology-negative axillary lymph nodes correlates with traditional predictors of prognosis: an interim analysis of a prospective multi-institutional cohort study. Ann Surg 239: 828-840, 2004.

17. Tsuda H, Akiyama F, Kurosumi M, Sakamoto G and Watanabe T: Establishment of histological criteria for high-risk node-negative breast carcinoma for a multi-institutional randomized clinical trial of adjuvant therapy. Japan National Surgical Adjuvant Study of Breast Cancer (NSAS-BC) Pathology Section. Jpn J Clin Oncol 28: 486-491, 1998.

18. Cutler SJ, Black MM, Friedell GH, Vidone RA and Goldenberg IS: Prognostic factors in cancer of the female breast. II. Reproducibility of histopathologic classification. Cancer 19: 75-82, 1966.

19. Le Doussal V, Tubiana-Hulin M, Friedman S, Hacene K, Spyratos F and Brunet M: Prognostic value of histologic grade nuclear components of Scarff-Bloom-Richardson (SBR). An improved score modification based on a multivariate analysis of 1262 invasive ductal breast carcinomas. Cancer 64: 1914-1921, 1989.

20. Harvey JM, Clark GM, Osborne CK and Allred DC: Estrogen receptor status by immunohistochemistry is superior to the ligand-binding assay for predicting response to adjuvant endocrine therapy in breast cancer. J Clin Oncol 17: 1474-1481, 1999.

21. Mohsin SK, Weiss H, Havighurst T, Clark GM, Berardo M, Roanh le D, To TV, Qian Z, Love RR and Allred DC: Progesterone receptor by immunohistochemistry and clinical outcome in breast cancer: a validation study. Mod Pathol 17: $1545-1554,2004$

22. Clahsen PC, van de Velde CJ, Duval C, Pallud C, Mandard AM, Delobelle-Deroide A, van den Broek L and van de Vijver MJ: The utility of mitotic index, oestrogen receptor and Ki-67 measurements in the creation of novel prognostic indices for node-negative breast cancer. Eur J Surg Oncol 25: 356-363, 1999.

23. Elledge RM, Green S, Pugh R, Allred DC, Clark GM, Hill J, Ravdin P, Martino S and Osborne CK: Estrogen receptor (ER) and progesterone receptor $(\mathrm{PgR})$, by ligand-binding assay compared with ER, $\mathrm{PgR}$ and $\mathrm{pS} 2$, by immunohistochemistry in predicting response to tamoxifen in metastatic breast cancer: a Southwest Oncology Group Study. Int J Cancer 89: 111-117, 2000 . 
24. Love RR, Duc NB, Allred DC, Binh NC, Dinh NV, Kha NN, Thuan TV, Mohsin SK, Roanh le D, Khang HX, Tran TL, Quy TT, Thuy NV, The PN, Cau TT, Tung ND, Huong DT, Quang le M, Hien NN, Thuong L, Shen TZ, Xin Y, Zhang Q, Havighurst TC, Yang YF, Hillner BE and DeMets DL: Oophorectomy and tamoxifen adjuvant therapy in premenopausal Vietnamese and Chinese women with operable breast cancer. J Clin Oncol 20: 2559-2566, 2002.

25. Ueno H, Yoshida K, Hirai T, Kono F, Kambe M and Toge T: Quantitative detection of carcinoembryonic antigen messenger RNA in the peritoneal cavity of gastric cancer patients by real time quantitative reverse transcription polymerase chain reaction. Anticancer Res 23: 1701-1708, 2003.

26. Mitas M, Mikhitarian K, Walters C, Baron PL, Elliott BM, Brothers TE, Robison JG, Metcalf JS, Palesch YY, Zhang Z, Gillanders WE and Cole DJ: Quantitative real-time RT-PCR detection of breast cancer micrometastasis using a multigene marker panel. Int J Cancer 93: 162-171, 2001.

27. Stassen M, Jonuleit H, Muller C, Klein M, Richter C, Bopp T, Schmitt S and Schmitt E: Differential regulatory capacity of $\mathrm{CD} 25^{+} \mathrm{T}$ regulatory cells and preactivated $\mathrm{CD} 25^{+} \mathrm{T}$ regulatory cells on development, functional activation, and proliferation of Th2 cells. J Immunol 173: 267-274, 2004.

28. Benghiat FS, Graca L, Braun MY, Detienne S, Moore F, Buonocore S, Flamand V, Waldmann $\mathrm{H}$, Goldman $\mathrm{M}$ and Le Moine A: Critical influence of natural regulatory $\mathrm{CD} 25^{+} \mathrm{T}$ cells on the fate of allografts in the absence of immunosuppression. Transplantation 79: 648-654, 2005.

29. Xu D, Liu H, Komai-Koma M, Campbell C, McSharry C, Alexander $\mathrm{J}$ and Liew FY: $\mathrm{CD} 4{ }^{+} \mathrm{CD} 25^{+}$regulatory $\mathrm{T}$ cells suppress differentiation and functions of Th1 and Th2 cells, Leishmania major infection, and colitis in mice. J Immunol 170: 394-399, 2003.
30. Suto A, Nakajima H, Kagami SI, Suzuki K, Saito Y and Iwamoto I: Role of CD4(+) CD25(+) regulatory T cells in T helper 2 cell-mediated allergic inflammation in the airways. Am J Respir Crit Care Med 164: 680-687, 2001.

31. Zuo T, Wang L, Morrison C, Chang X, Zhang H, Li W, Liu Y, Wang Y, Liu X, Chan MW, Liu JQ, Love R, Liu CG, Godfrey V, Shen R, Huang TH, Yang T, Park BK, Wang CY, Zheng P and Liu Y: FOXP3 is an X-linked breast cancer suppressor gene and an important repressor of the HER-2/ErbB2 oncogene. Cell 129: 1275-1286, 2007.

32. Yokoyama H, Nakanishi H, Kodera Y, Ikehara Y, Ohashi N, Ito Y, Koike M, Fujiwara M, Tatematsu M and Nakao A: Biological significance of isolated tumor cells and micrometastasis in lymph nodes evaluated using a green fluorescent protein-tagged human gastric cancer cell line. Clin Cancer Res 12: 361-368, 2006.

33. Triest JA, Grignon DJ, Hillman GG, Kocheril SV, Montecillo EJ, Talati B, Tekyi-Mensah S, Pontes JE and Hillman GG: Systemic interleukin 2 therapy for human prostate tumors in a nude mouse model. Clin Cancer Res 4: 2009-2014, 1998.

34. Kodama T, Takeda K, Shimozato O, Hayakawa Y, Atsuta M, Kobayashi K, Ito M, Yagita $\mathrm{H}$ and Okumura K: Perforindependent NK cell cytotoxicity is sufficient for anti-metastatic effect of IL-12. Eur J Immunol 29: 1390-1396, 1999.

35. Comes A, Rosso O, Orengo AM, Di Carlo E, Sorrentino C, Meazza R, Piazza T, Valzasina B, Nanni P, Colombo MP and Ferrini S: CD $25^{+}$regulatory $\mathrm{T}$ cell depletion augments immunotherapy of micrometastases by an IL-21-secreting cellular vaccine. J Immunol 176: 1750-1758, 2006. 